\title{
Inspector of Hospitals Ralph Green and the Plague in Malta of 1813
}

\author{
Lt Col W Bonnici \\ MRCGP,DCH,RAMC*
}

24 Armoured Field Ambulance, Gaza Barracks, Catterick Garrison, DL9 4AU

SUMMARY: Bubonic plague reached Malta from Alexandria on 29 March 1813. The British garrison of about 370 men escaped lightly, with only twenty deaths. However, the epidemic brought the Army medical officers in conflict厉. with the Colonial Governor. This article looks at the turbulence generated by the plague among the medical staffi officers, and at the role they played in the Public Health Services of the island.

\section{Introduction}

Malta became a British possession in September 1800. It was administered by the garrison commander who acted as His Majesty's Civil Commissioner. However, in 1813 the Islands were formally annexed to the Crown, and a Governor was appointed to run the colony. LieutenantGeneral Sir Thomas Maitland was the first and most autocratic of the thirty-four British Governors. He arrived in Malta on 3 October 1813, and took command of the garrison from the ailing Civil Commissioner, LieutenantGeneral Sir Hildebrand Oakes. Maitland was soon in conflict with his medical officers. He rebuked Deputy Inspector of Hospitals Ralph Green and Garrison Surgeon Joseph Thomas for presuming to take upon themselves the functions of the Executive Government. Eventually, Maitland insisted that both be "expurgated" from Malta (1).

There was a schism in the medical department. Arthur Brooke Faulkner, Physician to the Forces in Malta from December 1811 to May 1814 , was highly critical of the Garrison Surgeon for failing to rigidly enforce the quarantine regulations. Brooke Faulkner was a vigorous advocate of the doctrine of contagion. His belief that the plague was only transmitted by contact differed from that held by Robert Calvert, an anticontagionist and Physician to the Forces in Sicily who, in August 1813, volunteered for plague service in Malta.

Maitland had no confidence in his medical staff, and maintained it absurd to suppose "that any medical man is a bit better judge than any other member of the community as how the plague is to be stopped and what are the measures to be adopted on the occasion" (2). He therefore kept his private counsel, and implemented his own measures to eradicate the plague.

\section{Green and the plague}

On 19 April 1813 the daughter of a shoemaker from the city of Valletta died of a very malignant fever. Several days later her mother became febrile, developed buboes in the groin and axilla and died on 3 May. Deputy Inspector of Hospitals Ralph Green was the Principal Medical Officer of the Malta garrison, and a member of the Committee of Health, presided over by Staff Surgeon Joseph Thomas. On being notified of these suspicious deaths the Committee of Health removed the family to the lazaretto. Green informed his regimental surgeons that he had that morning inspected the cadaver of a female who had died of plague. He urged them to be vigilant and tఱ inspect the troops frequently, as "it was very probable front the incautious life of a soldier, someone might receive the infection and communicate it to the rest of the garrison (3). Green assembled a medical board with Brooket Faulkner as president, and instructed him "to draw up few medical rules for the guidance of the Maltese" (3) However, the regimental surgeons found to their "mutuaP astonishment and distress", that none of them had eves seen the plague. "From the state of our knowledge of 保r disease," observed Surgeon William Stafford, 3rd Garris Tा Battalion, "we could have but little to recommend, and was chiefly to keep the bowels open by mild laxatives? drink plenty of lemonade.....to pay strict attention $\mathcal{F}^{2}$ cleanliness, frugality in diet, and temperance in conjugs $\overrightarrow{0}$ pleasures" (3).

Up to 13 May, the Committee of Health deluded itsig that the disease was completely under its control, and the only seeds that had taken root were securely shut ufs. within the lazaretto. The plague, however, marched or relentlessly. "It seemed to laugh at their exertions" said . Calvert, and "jumped from house to house and from street. to street. Those who had no communication together, as . well as those who had, fell alike victim to its fury" (4) Nevertheless, the people were still very sceptical that th plague was amongst them. To dispel the general disbelie in its existence, Green, Thomas and the Apothecary to the Forces William T Iliff published a proclamation affirming that "we who have seen and assisted in the examination of the bodies of several individuals who have died in the lazaret and in the city of Valletta, do certify that these individuals, did die of real and malignant plague" (5). Is order to check the spread of the pestilence, the Committes. of Health urged the government to suspend all commerciaळ activities. They also recommended halting all movemen within the city, severing contact with the countryside an $\Phi^{\circ}$ shutting up the people within their own dwellings for $D$. period of forty days. These measures were only partl送. implemented. The Committee of Health felt that the failure of the government to heed all their advice was not. only enabling the plague to spread unchecked, but was als directing the hostility of the people against them. On $2 \mathrm{co}$ June therefore they exhorted the Civil Commissioner to 
publish all the recommendations that they had given him. Oakes acknowledged that their suggestions had been beneficial, but had felt it inappropriate to implement them all, on the grounds of costs. He had always regarded the Committee of Health as a purely advisory body, and could not conceive how they had dared to presume otherwise. The health officials were unwilling to hold office without the powers to enforce their proclamations and resigned their office on 28 June. Oakes replaced them with an advisory Council of Health with himself as president, and Green and Thomas among its ordinary members (6). On 3 - July a medical police was raised to ensure compliance with the quarantine regulations. The plague in Valletta started to abate by the end of August. However, it was still raging fiercely in the countryside and on 11 September troops surrounded the infected villages so as to segregate them from the rest of the island. Oakes returned to England on 11 October 1813.

His successor was not one to rule by committees. On 29 November, Maitland abolished the Council of Health, and returned Green to his sole duties as Principal Medical Officer. The Governor claimed that the doctors had attempted to usurp the power of the state. He alleged that Green and Thomas had "taken it into their heads to enter into a new kind of political speculation and to attempt to ist up what I never heard of before, a government purely asiedical" (7). The Committee of Health, declared yaitland, has assumed "that because the plague existed, we whole island was a lazaret, and that because it was a wharet they had the right to govern it, and went on to force government into measures of expense, holding out the threat that if whatever they proposed was not executed, the government would become totally answerable for the health of the island and for any loss of lives that might ensue" (2). He, however, had "administered them such a dose that I presume they will go quietly in future without attempting to interfere with what does not belong to them" (7). Maitland insisted that the medical gentlemen were subordinate to the civil authority and that the "means of eradicating the evil are a function of government and have nothing to do with medicine or its professors, and rest solely upon the energy, activity and vigilance of the police in hindering communication and keeping every person out of contact with his neighbour" (2).

Eventually, the plague burnt itself out. The epidemic was declared over on 29 January 1814 , and this day was set aside for solemn prayers and thanksgiving to God.

\section{Plague and the Garrison - The Military Pest Hospital}

On 22 June 1813, a sergeant of the Regiment of De Roll quartered at the Auberge D'Italie in Valletta fell ill with a supposed common fever, and died on 28 June. Shortly afterwards, five soldiers in the same room contracted the infection. The plague then spread to the 3rd Garrison . Battalion stationed at Floriana Barracks. The 2nd Battalion 14th Foot at Lower St Elmo Barracks in Valletta, and the Sicilian Regiment in Floriana escaped infection. This was attributed to their strict isolation, and to their "inheritance of a sound constitution and difference in the mode of living" (8).

According to a contemporary description, the "pestilential fever makes its appearance with loss of appetite, violent headaches and from debility, excessive irritability takes place. A tumour of the quality of a whitlow forms in the neck, or under the arm, or knee, that seldom ever fails to kill the patient in ten or twelve hours, who dies raving mad. It is very rare if ever one recovers, unless the tumours ripen and burst" (9). About thirty to forty soldiers of the 3rd Garrison Battalion contracted plague, of whom eleven died. Surgeon W Stafford purged them all with Calomel. Calomel, mercurous chloride, was liberally prescribed to cleanse the bowels, as it was imperative to remove all residue of food lest it underwent putrid transformation and poisoned the body. Initially, the patients were treated under canvas, but in July a military pest hospital was set up in the convent of Saint Calcedonius at Floriana. Green was superintendent of the pest hospital. He appointed a steward, a cook, and two orderly men to work in the hospital, but neither steward nor cook were permitted to enter the sick room. Green directed the staff to pay the strictest attention to the personal cleanliness of the sick by frequently changing their bed and body linen. The rooms and corridors were to be washed and sprinkled with vinegar. When administering medicine or food to the sick, the attendants were advised to rinse their mouth with strong vinegar, and to suspend respiration for a while so as to avoid inhaling the noxious exhalations of the patient. A hospital mate on the staff of the garrison hospital in Valletta was detached for duty at the pest hospital. On 4 July, Mr Francis Dagenhart took up residence at the hospital. Dagenhart was relieved by hospital mate J Henry Milles on 30 July, and before returning to duty had to perform the obligatory quarantine at the lazaret. In early September, Milles was replaced by hospital mate Edward Hollier, who had arrived from Sicily in August for plague duty in Malta. None of the hospital attendants contracted plague. Green attributed this to his use of the "Oily Friction" and "Fumigation" of the wards and bed chambers. Early in the morning, before first visiting the sick, the hospital mates had to vigorously rub oil over their entire body, and to employ friction for three or four minutes to the parts most exposed to the air and furnished with the greater number of superficial lymphatic vessels and glands such as the legs, thighs, arms and neck. The mates covered their working clothes, consisting of a shirt, long trousers, buskins, gloves and cap, with a dress of oiled canvas (10). This protective clothing not only kept infected matter away from the skin, but also produced such copious perspiration which stopped the absorption of the toxin. Soldiers mounting guard had to anoint their bodies with oil and were supervised in the application of the oily friction by their medical officers. Green bought enough oil to last the garrison several months. This was of the finest quality so as not to nauseate the soldier with the smell of oil of an inferior grade. On changing guard the soldiers were obliged to wash 
themselves with vinegar and water before mingling with their comrades. Green also placed fumigating lamps at each patient's bedside and ordered the attendants to ensure that the lamps were filled up as required by day or night. The pest hospital was to be fumigated in accordance with the doctrine promulgated in the "Effects of the nitrous vapours in destroying contagion," published by J Carmichael Smyth in 1799. Staff Surgeon W H Burrell, Principal Medical Officer in Malta in 1852, states that from twenty to thirty patients were treated at the pest hospital (11). Green visited the patients twice daily.

Arthur Brooke Faulkner acted as physician to the pest hospital, but from 4 July to 2 August had only nine patients under his official care. Brooke Faulkner had been appointed Physician to the Forces by Sir Lucas Pepys on 28 July 1808, and served on Sir David Baird's expedition in the Peninsula and at Walcheren. In January 1811, he was ordered to Sicily. Maitland described him as an "extremely troublesome gentleman who had been turned out of every situation in which he had been placed" (12). While in Sicily, Brooke Faulkner clashed with Inspector of Hospitals James Borland, head of the medical staff in the Mediterranean, and was censured for insubordination. The Army Medical Board attributed his actions to inexperience and hoped "that he will in future conduct himself accordingly to the rules of the service" (13). Nonetheless, the death in Malta of Physician to the Forces William Irvine in May 1811 created an opportune vacancy, and on 11 December 1811 Brooke Faulkner was placed on the strength of the Malta garrison. Brooke Faulkner had no experience of the plague. He therefore sought permission to visit the civilian pest hospitals in order to obtain some useful knowledge of the disease and its treatment. Oakes refused "so that the army might not be deprived of medical assistance in the time of need" (8). "This prohibition of a medical officer from visiting the sick", commented Brooke Faulkner, "so far from being an eligible measure, was calculated to oppose the most complete impediment against availing the army of any benefit whatsoever from their advice by shutting out the only satisfactory inlets to medical knowledge. If this be not admitted, it must follow, I should think, that it was of very little consequence whether medical men were employed or not" (8). Eventually, he was allowed just half an hour to visit the local pest hospital. Oakes forbade his medical officers from checking the patient's pulse, even through a tobacco leaf and with every possible precaution. Thus, Mr John Allen, the Principal Naval Surgeon in Malta, was "confined to his house for twenty five days for having felt the pulse of a man in his own particular department, and though after the contact he used every kind of care to prevent the absorption of the virus" (8). At the military pest hospital Brooke Faulkner prescribed blood letting with the lancet or by the application of leeches. He also administered mercury and camphor, but did not consider calomel of use in the treatment of the plague. Mercury was a universal stimulant. Camphor was a powerful sudorific that washed away the morbid matter through the production of copious sweat. Brooke Faulkner alsce employed hydrotherapy and found the use of cold affusion? and the application of turpentine extremely useful. In spite of their treatment, nearly half of the patients under the care of Brooke Faulkner survived.

\section{The plague in Gozo and the death of George Craig McAdam}

On 29 January 1814, Malta was declared free of plagues and all restrictions were lifted. Physicians Calvert and Brooke Faulkner left Malta for Sicily to join Lordw Bentinck's expedition to Genoa. However, the Board of Health in Sicily would not allow them to land. They returned to Malta on 11 March and found that the plague had broken out in the neighbouring island of Gozo. The news of an outbreak of fever in the village of Xaghra ha reached Maitland on 3 March. Maitland was determine $\bar{B}$ to stamp out this foci as quickly as possible, as the closure of the Mediterranean ports was seriously affecting thet revenues of the Island. Accordingly, on 7 March detachment of troops from the Sicilian Regiment was sent over to isolate the village. Physician to the Forces George Craig McAdam, who had arrived in Malta in January 1814? accompanied the troops to Gozo. McAdam was relatively junior physician, having been promoted to Staff from the 20th Regiment of Light Dragoons on 3 September 1813. On 19 March a farm house at southern extremity of the village was converted inte plague hospital. McAdam visited this hospital regulagye and in breach of the quarantine regulations returned to $1 i^{\circ}$ lodgings at the nearby Franciscan convent. The plaside was confined to the village of Xaghra, and was in decli by the middle of April. No cases had been reported fo 5 twenty days when McAdam, who "had been much too ap? to mix with the infected", contracted the plague and die\& on 6 May (14). As to how he had contracted the infection McAdam stated that "he had been in the habit of exposing daily in the air the jacket in which he went to the lazareg the moment he returned, but that thinking all danger was ap an end, he had left off that precaution and thrown it into के heap of dirty linen in the corner of his room, where it has laid for 10 days, and that coming in from riding two daye before he was seized with the plague, he had taken off his coat and put on his jacket" (14). Staff surgeon James Do Tully attributed the death of McAdam "whose exertions were unceasing in the cause he had undertaken....to his want of belief in the contagion" (15). Maitland complained that after McAdam had contracted the plague he "styled it the rheumatism which led to a most unpleasant uncertainty to most of the officers who hac communicated with him. The conduct of this gentleman was most reprehensible and if he had been a common man he would have been liable to suffer death for it" (14). Ond other death followed that of McAdam and the plague in Gozo ceased on 28 May 1814. 


\section{Quarantine and the theory of Contagion}

Plague was considered to be a contagious disease "communicable by contact only, and different in that respect from epidemic fever, but whose extension and virulence is considerably modified by atmospheric influence" (16). Green and Brooke Faulkner were contagionists. They believed that close contact or very near approach to the person was essential to contract plague, unlike smallpox which may be passed on without contact merely by being in the same room or at considerable distance from the patient.

On 29 March 1813 the brigantine San Nicola arrived from Alexandria where plague had been raging for a while. The crew disembarked into the lazaret, after taking the usual precautions of shaving their heads, washing themselves with sea water and vinegar, and leaving their clothes on board. On 1 April the captain of the San Nicola and his servant died while performing quarantine, and were interred at the Lazaret. The plague then obtained a foothold in the city of Valletta. Brooke Faulkner castigated Joseph Thomas for not opposing with vigour the first advances of this deadly enemy. The quarantine system seemed to him "to be so extremely lax from the beginning that it would have been next to impossible the disease should not have been widely disseminated through the island" (16). Brooke Faulkner remonstrated that when the plague first broke out, the attending physician was allowed to wander the city before being subjected to any quarantine restrictions, and that for several weeks after the plague had entered Valletta the inhabitants were not segregated and shut up in their own houses, until three months after the onset of the epidemic.

The anticontagionists, however, regarded plague as an epidemic disease which was the result of a change in the local environment, and which operated simultaneously upon a part or the whole of a community. Robert Calvert, a Physician to the Forces since 22 October 1807, maintained that a contaminated person radiated infection to his immediate vicinity by generating a personal and highly localised miasma. He asserted that the pestilential effluvium had originated in "the bodies of those two men who died and were buried in the Lazaret," and that the contagion had been spread through the atmosphere (4). "In the spring or summer season a single infected person is sufficient to contaminate the air of a whole city." declared Calvert, and "those who happen to be then exposed to febrile causes are the first to become its victims, and these newly infected persons then generate a fresh supply of poison which increases in strength and influence, till at length it becomes so powerful that nothing but the winter season will entirely put a stop to it" (4).

In Malta the contagionist held sway. The sick were removed to pest hospitals and those who had contact with them secluded in lazarettos. Infected villages were isolated from the rest of the island by a cordon of troops or by the erection of a double wall. Inanimate objects were also deemed susceptible to retain the contagion, and these were either burned, aired, or fumigated in the hope of exterminating the contagion.

\section{Green and the Quarantine Department}

The Department of Quarantine was a civil rather than a military concern. Its role was to safeguard the public from contagious diseases, and in particular against the contagion of the plague. The Superintendent of Quarantine ran the lazaret and received an annual salary of $£ 800$. Passengers from suspect countries were kept under observation for forty days, and their belongings were fumigated with a gas produced from the ignition of a mixture of sea salt, manganese and an aqueous solution of sulphuric acid. On 10 July 1801, Mr William Eton became the first Superintendent of Quarantine. However, he claimed ill health and in August 1802 returned to England on sick leave. In his absence the duties of the quarantine department were gratuitously performed by Inspector of Hospitals William Franklin, Principal Medical Officer in Malta. In December 1806, Green succeeded Franklin as acting Superintendant of Quarantine. He also took up the post of President of the Board of Health, an appointment previously held by Franklin. Green found the running of the quarantine department irksome and time consuming. $\mathrm{He}$ had to run the gauntlet of British merchants who were constantly enquiring about the duration their merchandise had to remain in the lazeret. Eton returned to Malta in September 1811, but was soon replaced by William Pym, Deputy Inspector of Hospitals at Gibraltar. Green "felto mortified and disappointed that an individual who was serving in Gibraltar with the same commission as I was in Malta, should be placed at the head of the health department, which in everything relating to the public health had been under my superintendence for several years and the duty gratuitously performed" (17).

Ralph Green joined the army on 6 May 1787. He hailed from Wales. At the age of nineteen he obtained a commission without purchase as a surgeon's mate to the 44th Foot. He became Surgeon to the Forces in 1795 and served in Flanders (1793 to 1795), the West Indies (1795 to 1798), and the Mediterranean (1799 to 1814). In January 1801 Green was an Inspector of Field Hospitals on Abercromby's expedition to Egypt. On his return to Malta in October 1801, Green served on the medical staff of the garrison. He became an Inspector of Hospitals on 29 June 1802 , but as his commission had not been notified to the General Officer commanding the Mediterranean, Green retained the rank of Deputy Inspector. In February 1807, he accompanied the expedition of Major-General Fraser to Alexandria as its Principal Medical Officer. While on this second Egyptian expedition Green solicited for promotion as Inspector of Hospitals, but this was rejected as there was already one Inspector on the strength of the headquarters of the Mediterranean.

William Pym was junior to Green. He was appointed surgeon's mate of the 35th Foot on 24 February 1792. While serving with the 35 th Foot in the West Indies, Pym had obtained unparalleled experience in the management of yellow fever. In October 1795, Pym moved to Gibraltar 
where he ran the quarantine department for thirteen years. He was thus better qualified for his new post than Green. Pym arrived in Malta at the beginning of March 1812 and criticised Green for leaving the department in "a mass of confusion and plunder scarcely producing income sufficient to pay its expenses" (18). During his very short stay in Malta, Pym established new regulations that improved the running and increased the revenue of the department. However, he considered his position in Malta inferior to that held in Gibraltar, and on 4 May 1812 returned to England on sick leave. Maitland said that Pym "in the short space of one month had published a most foolish and non effective set of regulations. He then made his bargain with a deputy to receive three-fourths of the salary and has never been seen since, and the person whom he approved was most incompetent" (19). This so called "incompetent" was Staff Surgeon Joseph Thomas who had arrived in Malta on Abercomby's expedition. On his return from Egypt, Thomas served as an Apothecary to the Forces, and became Garrison Surgeon on 2 June 1804. On the outbreak of plague in Malta, Pym declined to resume his post, as he was still in "bad health induced by a long residence in warm climates and repeated attacks of liver complaints" (18). Thomas, therefore, carried on with the management of the quarantine department and the presidency of the Board of Health. Oakes thought highly of Thomas and had no hesitation in recommending him as Pym's successor. Maitland, however, disagreed. "My opinion on that subject is widely different and I certainly cannot recommend that either that gentleman or Mr Green be applauded for their conduct as they have done much to confuse and embarrass, but little indeed to systemise or regulate" (20).

On 8 July 1813, Deputy Inspector of Hospitals Robert Grieves succeeded Pym as Superintendent of Quarantine, but did not reach Malta till November. Grieves was no stranger to Malta. He had been Staff Surgeon on Abercomby's expedition to Egypt, and at the end of the campaign lived on the island as Surgeon to the Forces until 1806, when he became a Deputy Inspector and moved to Sicily. Green did not hide his unhappiness at being once again denied the vacancy to which he had aspired. "The Army Medical Board" said Green "recommended my promotion to Inspector of Hospitals in Malta, but this recommendation has not been attended to, and all the consolation I have had since, is to see many of those who were my juniors in the service, promoted to that rank which was considered as my due by the superiors of my own department, and by the gentlemen whom I served, merely because I am shut up from other services much against my wish" (17). On 26 August 1813 Green was finally appointed Inspector of Hospitals and was instructed by the Army Medical Board to remain in Malta. Maitland would have none of it. "The idea of having an Inspector here is perfectly absurd and useless" said Maitland. "May I therefore entreat that he may be moved and that Mr Staff Surgeon Thomas be sent to some other quarter, for as long as we have our medical men interfering with government and dabbling with our merchants it is impossible we can ever get our health office placed on the footing it should be" (21). In December 1813 Grieves took over the duties of the quarantine department from Thomas, and alsoo replaced Green as Principal Medical Officer of theẹ. garrison.

\section{Epilogue}

History records several occasions of doctors losing을. favour with the civil authorities. In 580, for example, the King of Burgundy executed two surgeons when his Queen died of plague soon after they had incised her bubo. s. Inspector of Hospitals Ralph Green fell foul of Sir Thomas-; Maitland for his unpardonable conduct towards the Civil? Commissioner. Green had shepherded the Army Medical $\vec{\omega}$. Department during its very early days in Malta, and hade superintended the garrison throughout the Napoleonic era. Malta then served as a depot for medical stores for the British Army of the Mediterranean, a place of confinement for French prisoners of war, and a staging post for troops + to Sicily, the Levant and the Ionian Islands. Oakeso regarded Green as a "most worthy man and a very zealous' and meritorious officer" (22). Unfortunately, Green was deemed by Maitland to have overstepped his authority while serving on the Committee of Health, and Maitlafic insisted on his removal from Malta. In January $18 \mathrm{k} 4 \mathrm{O}$ Green left the Island for the Eastern Coast of Spain. was relegated to half pay on 25 February 1815, as Napoleonic Wars approached their conclusion. However, he was recalled to the Service on 10 April 1817, and se्gite. as the Principal Medical Officer to the West Indies. Aferer four years in the West Indies Green returned to England in extreme ill health and was placed on a military allowant of 30 shillings a day. He was then fifty years old and stillo unmarried. In 1828 Green deputised for Pym, theng Superintendent General of Quarantine in England, when $\mathbb{8}$ the latter left to oversee an outbreak of yellow fever in Gibraltar.

Inspector of Hospitals Ralph Green lived in ArgylE Street London, where he died on 17 June 1837, aged seventy years.

\section{REFERENCES}

1. Public Record Office (PRO): CO 158/24, 16 Nov 1813 Maitland to Bunbury.

2. PRO: CO 158/39, 27 Oct 1813 Mailtand to Bathurst

3. STAFFORD W: Observations on the plague in Malt Edin Med \& Sur J 1816; XLV: 13-21.

4. Calvert R: An account of the origins and progress of the plague in the island of Malta in the year 1813 Medico Chirurgical transactions 1815; 6: 676.

5. CO 158/22, 24 May 1813 Government notice.

6. PIRo De C M : Raggualio storico della pestilenza cheafflisse le isole de Malta e Gozo negli anni 1813 N 1814. Livorno 1833.

7. CO $158 / 40,28$ Oct 1813 Maitland to Torrens.

8. BROOKE FAULKNER: Observations of the plague as it lately occurred in Malta. Edin Med \& Sur J. 1 Aprik 
1814; 10: 137-168.

9. CO $158 / 23,7$ Aug 1813 Aldridge to Bathurst.

10. CO 158/23, 11 Aug 1813 Green to editor Giornale di Malta.

11. BuRRELL W H: Report on the plague of Malta in 1813 presented to both Houses of Parliament by command of Her Majesty. General Board of Health Appendix V to the second report on quarantine. London 1854.

12. CO 158/24, 20 Mar 1814 Maitland to Banbury.

13. PRO: WO 7/109, 24 Sept 1811 AMB to Borland.

14. CO $158 / 24$, 15 May 1814 Maitland to Banbury.

15. TULLY JD; The history of the plague as it lately appeared in the islands of Malta, Gozo, Corfu, Cephalonia. London 1821.

16. Report from the select committee appointed to consider the validity of the doctrines concerning the nature of contagious and infectious diseases as distinguished from other epidemics. 14 June 1819.

17. CO 158/23, 4 Sept 1813 Green to Bathurst.

18. CO $158 / 23,15$ Apr 1813 Pym to Bunbury.

19. CO 158/39, 5 Dec 1813 Maitland to Sidmouth.

20. CO 158/39, 16 Nov 1813 Maitland to Bathurst.

21. CO 158/25, 21 Nov 1813 Maitland to Bunbury.

22. CO 158/17, 24 Nov 1811 Oakes to Bunbury.

\section{OBITUARIES}

Regimental Headquarters would welcome selfwritten obituaries and when completed they should be forwarded to Regimental Secretary RHQ, RAMC, Keogh Barracks, Ash Vale, Aldershot, Hants GU12 5RQ. 